\title{
THE FACTORS WHICH INFLUENCE THE RELATIONSHIP BETWEEN A NETWORK'S SYNERGIZING CAPABILITY AND THE INCREASE IN A SALESPERSON'S PERFORMANCE
}

\author{
Ida Bagus Nyoman Udayana ${ }^{{ }^{*}}$, Naili Farida ${ }^{2}$ \\ ${ }^{1}$ Department of Management, Faculty of Economics, Universitas Sarjanawiyata Tamansiswa \\ Yogyakarta \\ ${ }^{2}$ Department of Management Sciences of the Doctoral Program of Faculty of Economics and \\ Business of University of Diponegoro in Semarang Central Java Indonesia
}

\begin{tabular}{|c|c|}
\hline ABSTRACT & ARTICLE INFO \\
\hline $\begin{array}{l}\text { Introduction: This research aims to explore the concept of customer } \\
\text { networks in the context of sales. A research model is proposed to explain } \\
\text { how a salesperson's performance is increased by synergizing the } \\
\text { network. Background Problems: There are inconsistent research } \\
\text { findings on the relationship between adaptive selling and salespeople's } \\
\text { performance. The proposed research question is whether adaptive selling } \\
\text { has an effect on a salesperson's performance through his/her customer } \\
\text { networking capability or not? Novelty: the novelty of this research is the } \\
\text { analysis of the capabilities of customer networking, based on information } \\
\text { sharing, promotion sharing, and knowledge sharing. Research Methods: } \\
\text { This research involved } 266 \text { salespeople from the soft drinks' industry. } \\
\text { The hypotheses were tested using structural equation modeling. } \\
\text { Findings: The results of the study show that adaptive selling is able to } \\
\text { increase a salesperson's performance through their customer networking } \\
\text { capability. The customer's order quality, adaptive selling and communi- } \\
\text { cation quality have significant positive effects on the capability of the } \\
\text { customer network. Furthermore, the customer's order quality, retention, } \\
\text { and communication quality have significant positive impacts on the } \\
\text { salesperson's performance. The variable which has the most influence on } \\
\text { the increase in the salesperson's performance is communication quality. } \\
\text { Conclusion: This study concludes that the ability of the customer } \\
\text { networking capability to link between adaptive selling and the } \\
\text { salesperson's performance is real. Additionally, the quality of the } \\
\text { customer's orders, retention and the quality of their communications give } \\
\text { significant positive effects to a salesperson's performance. Therefore, } \\
\text { companies should pay special attention to the salespeople who perform }\end{array}$ & $\begin{array}{l}\text { Article history: } \\
\text { Received } 21 \text { October } \\
2017 \\
\text { Received in revised form } \\
23 \text { November } 2017 \\
\text { Received in revised form } \\
16 \text { November } 2018 \\
\text { Received in revised form } \\
22 \text { May } 2019 \\
\text { Accepted } 27 \text { May } 2019\end{array}$ \\
\hline
\end{tabular}

\footnotetext{
* Corresponding author at the department of Management, Faculty of Economics, Universitas Sarjanawiyata Tamansiswa, Jalan Kusumanegara No. 121, Yogyakarta 55165, Indonesia.

E-mail address: ibn.udayana@yahoo.co.id,2nailifarida@gmal.com
} 


\section{INTRODUCTION}

Salespeople's performance is one of the important factors which determine the performance of a company. There are many factors contributing to the success of the salespeople's performance. The role of the salesperson in building networks or relationships is one of the keys to determine the salesperson's contribution (Bolander, Satornino, Hughes, \& Ferris, 2015). The business environment requires marketing departments to pay attention and improve their sales forces' skills, to improve their marketing. Besides that, the role of brand advertisement can also motivate a salesperson to work harder (Hughes, Bon, \& Rapp, 2013).

It is very important to develop customer networks. Indonesia is a place where such networks could be created. There are many factors that support the growth of customer networks there, such as the Indonesians' culture of forging friendships. Customers who have an emotional bond with a company tend to be loyal to that company and will spread positive information to other people about the company. Special skills are needed to make this happen.

The skills of a salesperson have long been identified as the determinant of a salesperson's performance. Besides attitude, perception, motivation, personality and organization factors, skills in marketing also have an impact on their marketing performance (Basir. \& Ahmad, 2010). Furthermore, Basir \& Ahmad (2010) classified marketing skills into three dimensions, namely: personal skills, technical and marketing skills. These three dimensions have been used as strategies to assess a salesperson's performance.

Although methods have been introduced to predict the marketing performance, not many people examine these at the individual level, which contributes to the success of a salesperson. Salespersons who can adapt when interacting with customers can increase their sales performance with experience as an intervening variable (Mariana, 2013; Singh Saini $\&$ Moon, 2013). Salespeople who are focused on their customers and have a great deal of experience can raise their performance (Amyx, D., and Jarrell, L, 2016; Mulki, J. P et al., 2015). Thus, how important is it to build trust in customers?

Salespeople are required to develop customer networks (Luo, Hsu, \& Liu, 2008). An extensive customer network is a long-term investment for the company. Networking is a way for salespeople and customers to meet, faceto-face. Networking is a method where customers can find out about, try and evaluate the company's services or products. Customer networking is important because the extent of the networking is an effective strategy to fight off the increasingly dynamic competition (Hajli \& Lin, 2016). Besides, networking is an investment that has long-term benefits. Extensive customer networks have the potential to improve the sales performance, because of the wider network, and the increasing number of customers. Increased numbers of customers can improve the sales performance. So far, customer networking's management has not been optimized. Customer networks have been around for some time, and they need professional guidance and maintenance. Thus, salespeople must be able to understand the needs and desires of their customers, who tend to be dynamic. Therefore, it is necessary to develop systematic and structured family-based networks, a network of customer-based principles that are mutually beneficial, and customer networks that can take place on an ongoing basis.

High quality communication is needed to build the customers' trust (Park, Lee \& Lee, 2014; Leszczyński \& Zieliński, 2013). Maintaining a collaboration and a good relationship 
with customers is the key to a successful organization. Collaboration can be realized in the form of providing excellent service, in the hope that the customers will get satisfaction. If the customers' trust can be maintained and improved, they will feel satisfied. Customers who are satisfied with a company's services can increase its sales performance. Companies must be able to understand the needs and the desires of their customers to improve their sales performance. Sales performance can be increased if it is supported by the sales forces' ability to resolve the problems faced by their customers. Adaptability is one key factor that improves sales performance. However, the findings of some researchers show various inconsistencies.

There are inconsistent research findings for the relationship between adaptive selling and salespeople's performance. Several researchers claim that adaptive selling has an impact on the salesperson's performance (Chirani, and Matak, 2012; Kidwell et al., 2007; Singh and Das, 2013; Singh \& Koshy, 2011). However, several other researchers claim that adaptive selling does not have a positive impact on the salesperson's performance (Abed and Haghighi, 2009; Markose, 2011). Based on the research gap between adaptive selling and salespeople's performance, the researchers fill that gap by proposing a new variable called the customer networking capability. The aims of this research are to examine and analyze the essence and the direct or indirect role of adaptive selling, customers' order quality, the communications' quality, and customer retention on the customer networking capability so that it increases the salesperson's performance. In addition, this study aims to develop an empirical model that bridges the research gap between adaptive selling and a salesperson's performance by building a new concept; namely the customer networking capability.

\section{LITERATURE REVIEW}

Salepeople's performance is evaluated by the total annual incentive per salesperson, which is based on the amount each one sells. The bonus is gained by the volume of sales of the product to customers in one area, which is compared with the initial estimate of the year's sales, and on this basis the compensation is awarded, or not, to the salesperson (Charles, H., and Schwepker, J. 2015). The successful sales of the product can be seen from the total number of units sold, the income, market, and the ability to make a profit (Carter et al., 2014; (Cartera, Hendersonb, Arronizc , \& Palmatierd, 2014; David A, Mulki, \& Weinberg, 2014; Drollinger \& Comer, 2013). The behavior of the salesperson can be identified from the skills he/she possesses, including being an adaptive seller, good - teamworking skills, effective communication and being consumeroriented in his/her selling activity, sales calls, time management, and comprehension of the sales area (Gablera, Rapp, \& Richeyb, 2014; Kumar, Sunder \& Leone, 2014).

Their customer orientation has a significant positive impact on the customers' trust in the salesperson (Guenzi et al., 2011; Guenzi \& Georges, 2010). The other finding was the salesperson's likeability has no impact on the customers' trust in them. The customers' trust in the salesperson has a significant positive impact on the their intention to buy, their recommendation to others, and reduces their intention to move to another competitor's brand (Fang Yulin et al., 2014). Consumers who are satisfied tend to repurchase, but not only do they repeat their purchases, they also recommend that their friends, colleagues, family, and other close relatives do the same thing (Dubihlela, J., \& Molise-Khosa, 2014; Vatani et al., 2014).

The cultural organization's difference and socialization are associated with personal organization and relevant outputs such as a 
controllable social environment, higher creativity, higher selling performance and increasing the salesperson's loyalty to their job, salesperson's job satisfaction increases (Lopez \& McMillan-Capehart, 2009). The employee's performance and loyalty are affected by psychological factors, like self-efficacy, selfconfidence, and staff's job satisfaction as an intervening variable. Another finding shows that psychological empowerment is affected by items in the internal marketing dimension, like internal promotions (Yao, Q, et al., 2013).

Adaptive selling is a salesperson's ability to communicate with customers, by adjusting to their behavior, meeting someone who needs that product and giving an optimal service (Maroofi, Sadegh, Sadegh \& Fathi, 2011). The salespeople must be able to adjust themselves when dealing directly with their customers, because each person has his/her own different uniqueness and background. Adaptive selling is the ability of a salesperson to adjust his or her behavior when interacting with their customers, based on the information that he/she gains about the marketing characteristics and situation at that moment.

Adaptive selling is changing the behavior of the salesperson when interacting with customers (Johlke, 2006). Adaptive selling in this research model shows that this adaptive skill is associated with an increased performance by the salesperson (Chen and Jaramillo, 2014). Furthermore, Chen and Jaramillo (2014) stated that a salesperson's ability to maximize private adaptive selling is very crucial to building a long-term relationship with customers, and for improving specific skills to raise the salesperson's performance. The ability of the salesperson to use this adaptive selling skill is the second-best component after the sales presentation. Furthermore, adaptive selling is defined as the change in a salesperson's behavior so he/she can interact more easily with the customer, based on the information he/she gains. Moreover, the salesperson should use be flexible in his/her communications with the customer during the interaction process (Chirani and Matak, 2012; Kim, 2010; Singh and Das, 2011). The understanding of adaptive selling is closely related to the quality of the service provided to customers, it is very important for a salesperson to know their wants and needs.

The perception of a salesperson that is customer-oriented has a significant positive impact on adaptive selling via the ambiguity role, the intrinsic motivation, and the customerqualification skills. Adaptive selling can raise the salesperson's performance and the satisfaction of the customer (Chakrabarty, et al., 2013). Furthemore, it can create a good relationship with the customer.

Customer networking capabilities can improve business performance (Luo et al., 2008). A salesperson's performance can be increased if he/she can build and maintain good relationships with his/her customers. In addition, salespeople must be committed to providing the best service for their customers. Salespeople should pay proper attention to their customers, to maintain good relations and for their mutual benefit. Besides, good relationships need to be fostered with retailers, wholesalers, suppliers, and commercial administration bureaus. If all of this can be done well, these good relationships can improve the sales performance.

The ability of salespeople to retain customers (customer retention) really determines the success of synergizing customer networking. To retain their customers, salespeople must listen to the complaints and questions of their customers (Shoemaker \& Pelham, 2013). The customers feel valued if their complaints are heard with all sincerity. Thus, salespeople should pay attention to their customers by listening to all the 
questions asked, so they can show that they understand their customers' queries and needs. This can be done by repeating the customers' questions once again. Customers who feel cared for feel satisfied; they will find it difficult to switch to other products despite tempting offers. Thus, the customers will remain loyal and not move to other products.

Data from the Indonesian Central Bureau of Statistics show the performance of the soft drinks' industry tended to decrease year by year, except for 2007-2008. From 2009 to 2011 it decreased significantly. This indicates there was a problem with the salespeople (Kantor Pusat Statistik Indoesia, 2016). To fill the research gap between adaptive selling with salesperson performance, the researchers proposed a new variable, namely the customer networking capability. The aim of this was to raise the salespeople's performance.

Using literature as the basis to establish a model, we extend our understanding of the role of customer networking capability by testing and developing a model (Figure 1). We tested customer networking capability as the intervening variable that can assist us to explain how adaptive selling influences the salesperson's performance. Finally, we tested the impact of the customers' order quality, customer retention and communication ability on the salesperson's performance.

\section{HYPOTHESES DEVELOPMENT}

\section{Adaptive selling and customer networking capability}

Salespeople who are able to adapt easily when carrying out their duties and establish good quality relationships tend to improve their performance. Based on that fact, the quality of the relationship must be developed, both the relationship with the customer and the relationship with the supplier/ provider (Park and Deitz, 2006). The quality of the relationship will improve if the salesperson understands what his/her customers need and want. By assessing both aspects, the customers' satisfaction will be increased. Satisfied customers tend to make repeat purchases.

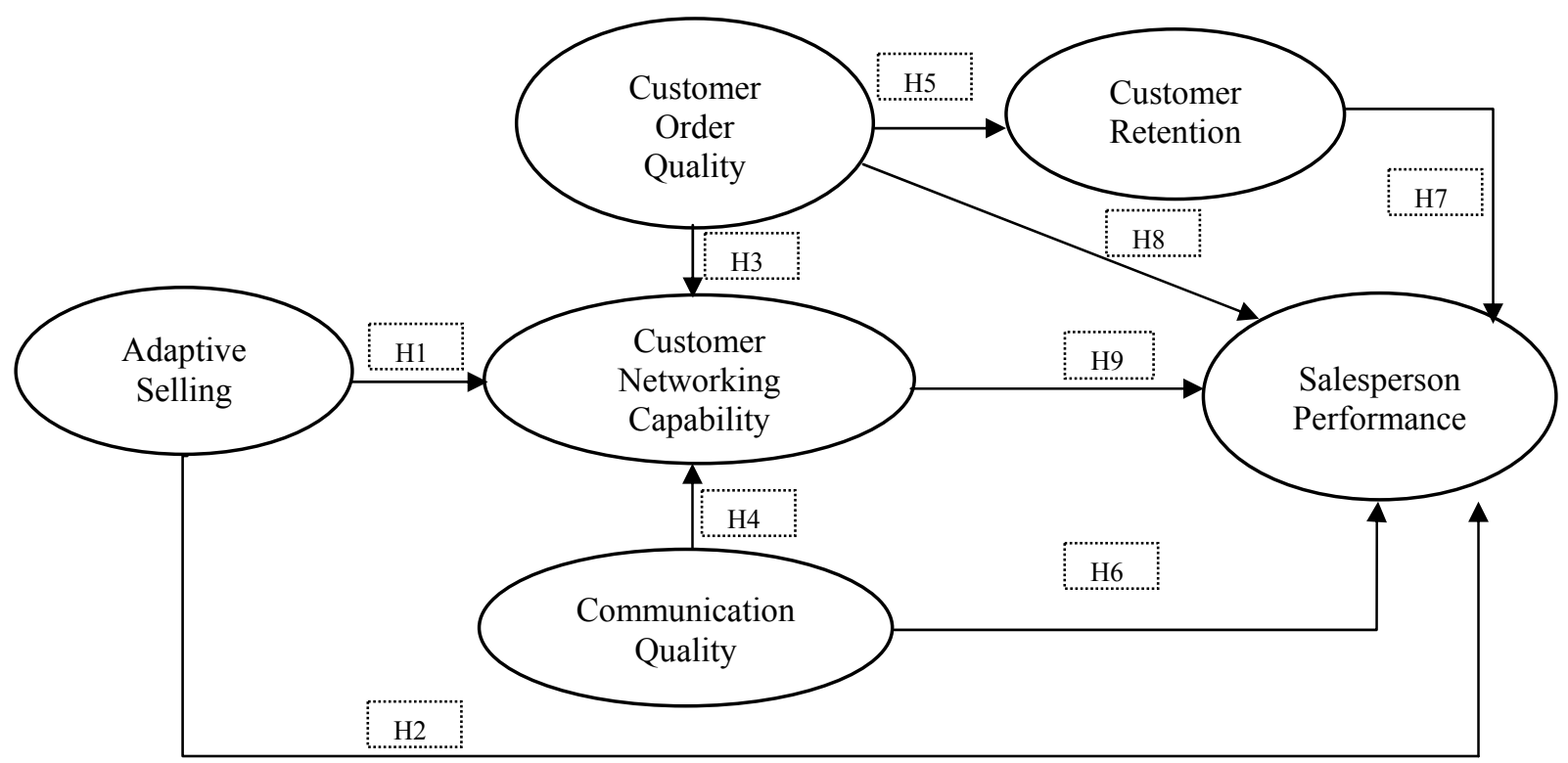

Source: author

Figure 1. Conceptual model with hypotheses 
A broad customer networking capability can also improve the salesperson's performance, since it provides mutual benefits for the customers (Le \& Nguyen, 2009). By broadening their customer network, salespeople are able to increase the number of new customers (Milovanovic, Primorac \& Geran, 2016) which is also beneficial for the company. Two of the ways to do that are by providing the best possible service to the customers and paying close attention to their needs and desires. As a result, the customers will be satisfied and tend to recommend the product or service that they use. The increased number of customers leads to the improvement of the customer network.

Maintaining good relationships can retain customers and this must be done by all business people, especially salespeople (Portera, Wienerb \& Frankwick, 2003). The ability to maintain a good relationship is beneficial to keep the customers from moving to other products. In order to establish this relationship, it is necessary to share experiences from using certain products with the customers. These processes include inputs from the customers about the products they have purchased and their personal levels of satisfaction. Based on the description above, the first hypothesis is as follows:

H1: The greater the salesperson's ability to adjust, when involved in interactions with a customer, the better his/her customer networking capability is.

\section{Adaptive selling and a salesperson's performance.}

There are various methods that can be used by a salesperson to improve their sales performance. One of them is the ability to adapt when interacting with customers (Chena \& Jaramillob, 2014; David et al.,2014; Jayakody \& Sanjeewani, 2006). When a salesperson feels that one approach is not working, it is necessary that he/she knows how to improvise according to the customers' characteristics. Another skill that has to be possessed by a salesperson is the ability to provide solutions to problems that might be faced by the customers, in order to keep them satisfied.

Sales performance is one of many tools to measure the success of a salesperson (Pettijohn., Pettijohn, Paylor, \& Keilor, 2007). Those who can achieve their sales targets are considered successful. Customer growth greatly determines the success of a salesperson, since the increased number of customers shows how good the performance of the salesperson is. In addition, customers who can expand the market share are also considered successful (Amyx \& Jarrell, 2016). The more capable a salesperson is at increasing the market share, the better the performance is. Therefore, the ability to adapt to customers is an important thing to have. Based on the statement above, the second proposed hypothesis is as follows:

$\mathrm{H} 2$ : The greater the ability of the salesperson to adjust, the better the salesperson's performance will be.

\section{Customers' order quality and customer networking capability.}

The ability of a salesperson to increase the number of goods purchased is a basic task. At the same time, it also can be used as a measurement of the success of a salesperson in developing a customer network (Cerri, 2012). Not only the number of items sold, but also the ease of the payments has a direct impact on the performance of salespeople and the company's profits. The greater the frequency of purchases by customers, the more the sales performance increases. Therefore, it is important to establish new markets and increase sales.

Customer satisfaction is the key to successfully expanding a synergized customer 
network (Chow, 2015). Customers who feel satisfied will make positive statements about the company and if this can be developed systematically and structurally, its customer network will increase. Thus, maintaining and increasing customer satisfaction can be done by paying attention to the complaints and needs of the customers. The company must ensure that speedy and accurate services are provided for their customers, which shows the customers' desires get attented to.

Increasing the salespeople's skills is a basic requirement for the successful development of customer networks (Ozdemir \& Hewett, 2010). This must be done in a dynamically growing environment. To deal with this condition, the only solution is to improve the quality of the salespeople's personal skills. Sharing knowledge with customers is also a pretty good way to develop customer networks. Salespeople can share experiences, both pleasant and unpleasant, with their customers. This ability is a way of synergizing customers (Milovanovic et al., 2016; Zheng et al., 2015). Based on the description above, the third proposed hypothesis is as follows:

H3: The greater the customers' order quality, the greater is the salesperson's customer networking capability

\section{The communication's quality and customer networking capability}

Salespeople who gain the trust of their customers must be maintained and improved (Rapp, Ahearne, Mathieu, \& Schillewaert, 2006; Schillewaert \& Ahearne, 2001). Creating a high quality product, in line with the customers' needs, is one way to communicate with customers. Collaborating with customers also determines the success of a salesperson, which leads to the widening of the customer network. Mutually beneficial cooperation is a basic requirement in expanding customer networks. Being friendly and polite are important for establishing mutually beneficial cooperation.

The synergy of customer networks can be built through maintaining good relationships with customers (Vilela et al., 2007). Maintaining good relations, by paying attention to the needs and desires of customers and providing them with the services they want, will keep the customers from switching to the competitors' products (Hajli \& Lin, 2016; Park \& Lee, 2014). Customer networks can also be developed by paying special attention to the customers, and simple things like offering congratulations on their special days such as birthdays, wedding aniversaries and such like (Milovanovic et al., 2016). By doing so, good relationships with the customers will be ensured. Based on the description above the fourth hypothesis can be proposed as follows:

H4: The greater the quality of the communication is, the better is the ability of the salesperson to increase the customer networking capability.

\section{Quality of customers' orders and customer retention}

These days, companies' attentions are more focused on retaining customers, not getting new ones (Ang \& Buttle, 2006). The first step in a company's customer life-cycle is to get new customers and execute some programs to maintain the existing customers. The success in getting customers is influenced by certain executive factors, the budget available to get customers and the use of technology (Zheng et al., 2015).

Customers who rarely complain about the quality of their order or its process are always better. In order to have this, careful inspection of the items before dispatch is a must. Handling complains must be dealt with as soon, and as 
well as possible to avoid disappointing the customers.

To survive increasingly dynamic competition, company owners must be able to make accurate strategies to maintain their market share. When competition is less, producers have to keep their customers by maintaining good relationships and increasing the knowledge of both parties, such as by improving the skills of the sales force through training. When competition is high, the producers maintain their customers by emphasizing innovation and learning from their competitors, for example by paying attention to the activities carried out by their competitors (Monteiro and Vieira, 2016; Voss and Voss, 2008).

H5: The greater the customers' order quality, the better the customer retention is.

\section{Communication's quality and salespeople's performance}

High quality communications are characterized by the maintenance of good and mutually beneficial cooperation between salespeople and their customers (Orpen, 1997). Good cooperation can be built through mutual trust and the spirit of finding solutions for problems faced by the customers. Always providing excellent service has the potential to further improve the communication. An excellent service can provide great satisfaction, which in turns leads to better quality communication with customers. A willingness to accept constructive criticism and advice from customers is also a good way to maintain the relationship (Park et al, 2014).

Good communication between customers, suppliers and distributors has a great impact on customers' satisfaction, which can be seen in their repeat orders (Park et al, 2014; Leszczyński and Zieliński, 2013). Nowadays, communication can be done by telephone, Instagram, WhatsApp, and other forms of social media. The quality of any communication is more important than the frequency of the communication. The number of repeat purchases directly improves the sales performance, which leads to an increase in the market share, increased company profits, and a larger marketing area. From the description above the sixth hypothesis is as follows:

H6: The better the quality of the communications, the better the performance of the salesperson.

\section{Customer Retention and Salesperson's performance}

Getting new customers and keeping them are the most important strategic steps carried out by a salesperson (Hennig-Thurau, 2000). In order to do that, communication skills are needed to maintain good relationships with the customers (Cartera et al., 2014). A good relationship can be be maintained if it includes mutual trust and has benefits for both parties. The customers' loyalty is a form of success and demonstrated by maintaining the existing customers. Two of the many ways to increase the customers' loyalty is to increase the programs that are beneficial to the customers and most importantly, maintain the product's quality and service (Stahl, Heitmann, Lehmann \& Neslin, 2012).

Customer satisfaction must always be maintained and improved to maintain the existing customers (Jonathan \& Johnmark, 2012). Therefore, a competent salesperson, who has gone through systematic and structured training, needs to carry out his/her duties properly (Liu \& Wu, 2007). The customers' trust and satisfaction play different roles in the relationship between service attributes and customer retention (Tawinunt, Phimonsathien, \& Fongsuwan, 2015). A professional salesperson is able to generate a strong enough feeling of trust with his/her customers to make them renew their orders, which impacts on the sales volume, 
profits, and marketing area. Based on the description above, the proposed seventh hypothesis is as follows:

H7: The greater the customer retention, the better the salesperson's performance

\section{Customers' order quality and salesperson's performance}

The quality of a customer's order is shown by the ability of the salesperson to fulfill their obligations when conducting transactions with his/her customers (Kenny \& Fahy, 2011; Shpëtim Çerri, 2012). Thus, the quality of the customer's orders can be measured by the number of complaints, the rate of return of the goods purchased, timely payments and the volume of goods purchased with relatively high prices.

The quality of a customer's order can be measured by how accurately the order is fulfilled. Speed and accuracy are necessary and must be done to the customers' satisfaction (Gil et al, 2005). Low interdependence can also improve the quality of the customers' orders. If there is high interdependence, there will be a decrease in the service quality. Interactions and the type of communication determine the quality of a customer's order (Abdul-Hafez \& Al-Nady, 2016). Good and smooth communications can help speed up the accuracy of a customer's order. Therefore, the type of communication has a significant positive effect on the quality of a customer's order.

The correct type of communication, which is in accordance with the local culture, is very effective in increasing the quality of the customers' orders (Yao, Chen \& Cai, 2013). The impact of effective communication has a significant positive effect on the performance of the sales force. Effective communication can increase the number of sales, expand the market share, increase the number of new customers and increase company profits (Park et al., 2014). In addition, it is necessary to improve the salesperson's skills, which can be done through training such as sales team skills, negotiation training and leadership skills training. Incentives may be offered, in the form of money or other things (Setia, Venkatesh \& Joglekar, 2013). So correct and accurate communications can improve the performance of the sales force.

Salespeople who can solve the problems faced by customers tend to make the customers stay with their company, rather than moving to a competing company (Milovanovic et al., 2016). Accuracy and speed of service determine the customers' satisfaction. Thus, the salespeople need to be able to give their customers their full attention (Singh and Das, 2011; Singh \& Koshy, 2011). From the above explanation, we generate the eighth hypothesis as follows:

H8. The greater the customers' order quality, the better the salesperson's performance

\section{Customer networking capability and salesperson's performance}

It is important for a salesperson to develop good methods of cooperation with his/her customers through their emotional ties. Cooperation can be effective if supported by highly emotional relationship. The emotional relationship supported by intelligence and hard work can create a direct impact on the sales performance. Professional and intelligent workers, who are willing to work hard, can expand their customer networks. To expand a network of customers takes hard work and perseverance, and involves learning from previous mistakes and from the success of their peers. Extensive customer networks can improve the salespeople's performance.

A salesperson's performance can be determined by their sales experience. A salesperson with greater work experience has a better 
performance (Pitt, Bertohon \& Robson, 2000). Experience obtained in the field is always the best; it is very important for a salesperson to have as much sales experience as possible (Gupta, 2016). Through the experience of selling, we can find the right communication pattern for each customer, since each of them has their own characteristics and cannot be compared with one another. Therefore, good cooperation will be established (Park and Deitz, 2006). The more collaborations that are carried out, the greater is the potential to improve the performance of a salesperson. Thus the ninth proposed hypothesis is as follows:

H9. The greater the customer networking capability is, the better the salesperson's performance will be.

\section{METHOD, DATA AND ANALYSIS}

\section{Sampling frame and data collection}

The researcher chose salespeople from small and medium entreprises because they had various empirical and theoretical characteristics which fitted the topic of dependence on customer networking. The population of this research was salespeople who sold various soft drinks in the province of Yogyakarta, and included the City of Yogyakarta, and Sleman, Bantul, Kulonprogo and Gunungkidul regencies. The samples were part of the characteristics possessed by the population.

The samples used in this research were 266 respondents who met the sample criteria recommended for a Maximum Likelihood Estimation (MLE) and Average Variance Extracted (AVE) of the indicator. The minimum sample's standard scale is to have at least five times as many observations as the number of variables to be analyzed (Hair Jr, Black, Babin, \& Anderson, 2010). A subsample is the subpopulation consisting of several sample members. The sub- sample is taken since in some cases it is impossible to employ all of the population (Ferdinand, 2014). The determination of the final number of samples (266) was because they met the criteria for a MLE and AVE of the indicator, with the minimum sample size being 150 , with a standardized loading factor of 0.7 (Hair, J, et al., 2010).

The data in this research were collected by using questionnaires, while the unit of analysis was the salespersons of the soft drinks' industry in Yogyakarta, Indonesia. The object of the research is a number of the soft drink companies in Indonesia. This study involved 300 respondents. However, only 266 respondents or $88.6 \%$ completed the questionnaire. The data were collected from January to June 2017. Then, the data collected were tested for validity and reliability (Ferdinand, 2014).

The 266 samples were taken from five districts, namely Yogyakarta city, and Sleman, Bantul, Kulonprogo, and Gunungkidul regencies. The details of the samples are as follows:

Table 1. Research Samples

\begin{tabular}{llcc}
\hline No & \multicolumn{1}{c}{ Area } & Total & Percentage \\
\hline 1 & Yogyakarta City & 56 & 21.1 \\
2 & Sleman Regency & 54 & 20.3 \\
3 & Bantul Regency & 53 & 19.9 \\
4 & Kulonprogo Regency & 50 & 18.9 \\
5 & Gunungkidul Regency & 53 & 19.9 \\
\hline \multicolumn{4}{c}{ Total } \\
Source: Data distribution of the questionnaire, established \\
& in 2015.
\end{tabular}

A sample's design level that can proceed well is called a rate response. A response below $80 \%$ can potentially create bias in the data (Imam, 2011). The respondents' responses, according to the accumulated data in this research were as follows: the number of respondents that were successfully given a questionnaire divided by the initial planned number of respondents. In this research, the 
response rate is $(266 / 300) \times 100=88.6 \%$. Thus, it can be concluded that the response rate is categorized as good.

The technique used to obtain the sample is purposive sampling. Purposive sampling is a deliberate technique for getting samples with the criteria: professional position as a salesperson for the soft drink's industry in the Yogyakarta area, having at least two years experience in the job, and being at least 17 years old. Purposive sampling is chosen as the sampling technique because researchers need information about sales, and only the salespeople really know what is happening. They need a minimum of two years work experience, because then they have enough information to be useful as respondents (Ferdinand, 2014).

It is confirmed that the sample of the salespeople met the standardized criteria. If the respondents did not meet the standardized criteria, they were not allowed to fill in the questionnaire. If they were identified after the data's entry, their data would not be processed.

The type of research is quantitative research. This is a type of research that focuses on numeric data for analyzing the data to draw a conclusion. To test the validity of the data, the researcher tested the data using a confirmatory factor analysis. To know the result, we analyzed the numeric data. The data is an interval scale.

\section{Measurement}

All the scales we used had previously been developed and were obtained from the literature. The questionnaires were directly used but some were modified to meet the research's objectives. All variables were measured using a 10-point Likert scale, ranging from 1 = strongly disagree to $10=$ strongly agree (Augusty, 2014).

We measured adaptive selling by modifying a five item scale used in previous studies
(Maroofi et al., 2011). A sample item is, "I use different approaches for different customers."

We measured the salesperson's performance by adapting a three item scale used in previous studies (Abed and Haghighi, 2009; Schwepker and Schultzb, 2015). A sample item is, "I have exceeded the sales targets set by the company."

For measuring the networking synergized variables, the writer was inspired by an article from Milovanovic et al. (2016) and Klerk (2014). A sample item is, "Maintaining a longterm relationship."

We measured customers' order quality by adapting a three item scale from previous studies (Phillips, McFadden, \& Sullins, 2010). A sample item is, "The customer is always satisfied with the items they bought."

We measured communication's quality by adapting a three item scale from previous studies (Abed \& Haghighi, 2009). A sample item is, "Maintaining collaboration with the customers."

We measured customer retention by adapting a three-item scale from previous studies (Anosike and Eid, 2011). A sample item is, "Maintaining good relationships."

As part of the initial research the respondents' age, sex and job experience were also tested. Since the researcher did not find any impact on some of the variables or their relation to the model, they were excluded from the advanced analysis.

The researchers did a confirmatory factor analysis to gain an accurate measurement before estimating the structural model, as per Hair, Black, Babin and Anderson (2010). The indicators that had a loading factor of under.50 were dropped. The statistical model was fit and acceptable, as its value was $(\chi 2=169.620$, $\mathrm{df}=140, \quad \mathrm{p}<.045 ; \quad \mathrm{RMSEA}=.035 ; \quad \mathrm{CFI}=.990 ;$ 
AGFI=.883; GFI=.914). Meanwhile, the total significance is $\chi^{2}$, ratio $\chi^{2}$ per $\mathrm{df}(1.212)$.

Next, the researchers evaluated the convergent and discriminant validities. The convergent and internal validities measure the real-items measurement that should be measured. To gain these analyses, we used a reliability analysis, where each construct has a Cronbach's alpha of over 0.75 (Hair et al., 2010). All the constructs with their loading factors, alpha coefficients, and average variance extracts are described in Table 2.

\section{Structural estimation model}

The structural model can be estimated if the measurement model has proved to be valid (Augusty, 2014). The researchers used a Structural Equations Model (SEM), to do the testing simultaneously and to consider any wrong measurements (Hair et al., 2010). The researchers used an $A M O S$ program, the most basic one is for covariance (AMOS 21). A direct impact model was used to evaluate the relationships presented in Figure 1. This model tested the relationship between adaptive selling and customer networking capability (H1) and the

Table 2. Scale items with loading factor: reliabilities and validity

\begin{tabular}{|c|c|}
\hline & $\begin{array}{c}\text { Standardized } \\
\text { loading }\end{array}$ \\
\hline \multicolumn{2}{|l|}{ Adaptive selling (Maroofi et al., 2011) $\mathrm{AVE}=.515 ; \mathrm{CR}=.809^{*} ; \mathrm{DV}=.718^{* *}$} \\
\hline When I feel that my approach was not working, I simply changed to another approach & .83 \\
\hline I use different approaches for each different customer & .73 \\
\hline I can easily overcome a customer's difficulties & .74 \\
\hline \multicolumn{2}{|l|}{ The customer order quality (Phillips et al., 2010) $\mathrm{AVE}=0.50 ; \mathrm{CR}=.79 ; \mathrm{DV}=.707$} \\
\hline The customer is always satisfied with the items they have bought & .91 \\
\hline The customer's order process is fast & .94 \\
\hline The payment process is accurate & .84 \\
\hline \multicolumn{2}{|l|}{ Communication quality (Abed \& Haghighi, 2009) $\mathrm{AVE}=0.50 ; \mathrm{CR}=.70 ; \mathrm{DV}=.71$} \\
\hline Maintaining a collaboration with customers & .74 \\
\hline Giving excellent service & .74 \\
\hline Willing to continue the collaboration & .86 \\
\hline \multicolumn{2}{|l|}{ Customer retention (Paschal \& Eid, 2011) AVE $=.50 ; \mathrm{CR}=.79 ; \mathrm{DV}=.71$} \\
\hline Paying full attention & .94 \\
\hline Quick in responding to the customer's complain & .95 \\
\hline Maintaining good relationships & .93 \\
\hline \multicolumn{2}{|l|}{$\begin{array}{l}\text { Networking synergized capability (Klerk, 2014; Milovanovic et al., 2016)AVE }=.52 \text {; } \\
\mathrm{CR}=.86 ; \mathrm{DV}=.79\end{array}$} \\
\hline Tightening family bonds & .95 \\
\hline Giving benefit to each other & .94 \\
\hline Developing relationships & .91 \\
\hline Maintaining a long-term relationship & .94 \\
\hline \multicolumn{2}{|l|}{ Salesperson performance (Miao and Evans (2012) $\mathrm{AVE}=0.54 ; \mathrm{CR}=.82 ; \mathrm{DV}=.73$} \\
\hline The selling always increases & .95 \\
\hline Growing customer numbers & .93 \\
\hline Extending market areas & .92 \\
\hline
\end{tabular}

${ }^{*} \mathrm{CR}=$ Construct reliability, ${ }^{*} \mathrm{DV}=$ Discriminant validity, $\mathrm{AVE}=$ average extracted 
salesperson's performance (H2). Additionally, this model tries to examine the relationship of customers' order quality and customer networking capability (H3) and the salesperson's performance (H8). Besides that, this model also tries to examine the relationship between customer retention and the salesperson's performance $(\mathrm{H} 7)$. Then we tested the relationship between communication's quality and customer networking capability (H4) and the salesperson's performance (H6). We then analyzed the influence of customers' order quality on customer retention (H5). Finally, it examined the relation of customer networking capability and the salesperson's performance (H9).

\section{RESULT AND DISCUSSION}

\section{Structural model and hypotheses testing}

The next task is analyzing the structural equation model, after doing the confirmatory factor analysis to ensure a valid and reliable confirmation for each construct. The full model analysis is done on the research model. The data analysis technique is described in Figure 2.

From Figure 2, it can be seen that adaptive selling has a significant positive impact on customer networking capability, and on a salesperson's performance. The customers' order quality has positive significance for the customer networking capability, customer retention, and salesperson's performance. Besides that, communication skills generate a significant positive impact on customer networking capability and on selling performance. Finally, the customer networking capability has a significant positive effect on the salesperson's performance.

Validity testing of the model is undertaken, using a goodness of fit index. Based on the testing result in Figure 2, the model is acceptable since it has fulfilled the necessary requirements: $\left(\chi^{2}=169.620 d f=140 ; p<.05\right.$, RMSEA $=.035$; $\mathrm{CFI}=.99)$ and all the hypotheses are accepted. Hypothesis 1 is the unsynergized correlation between adaptive selling and the customer

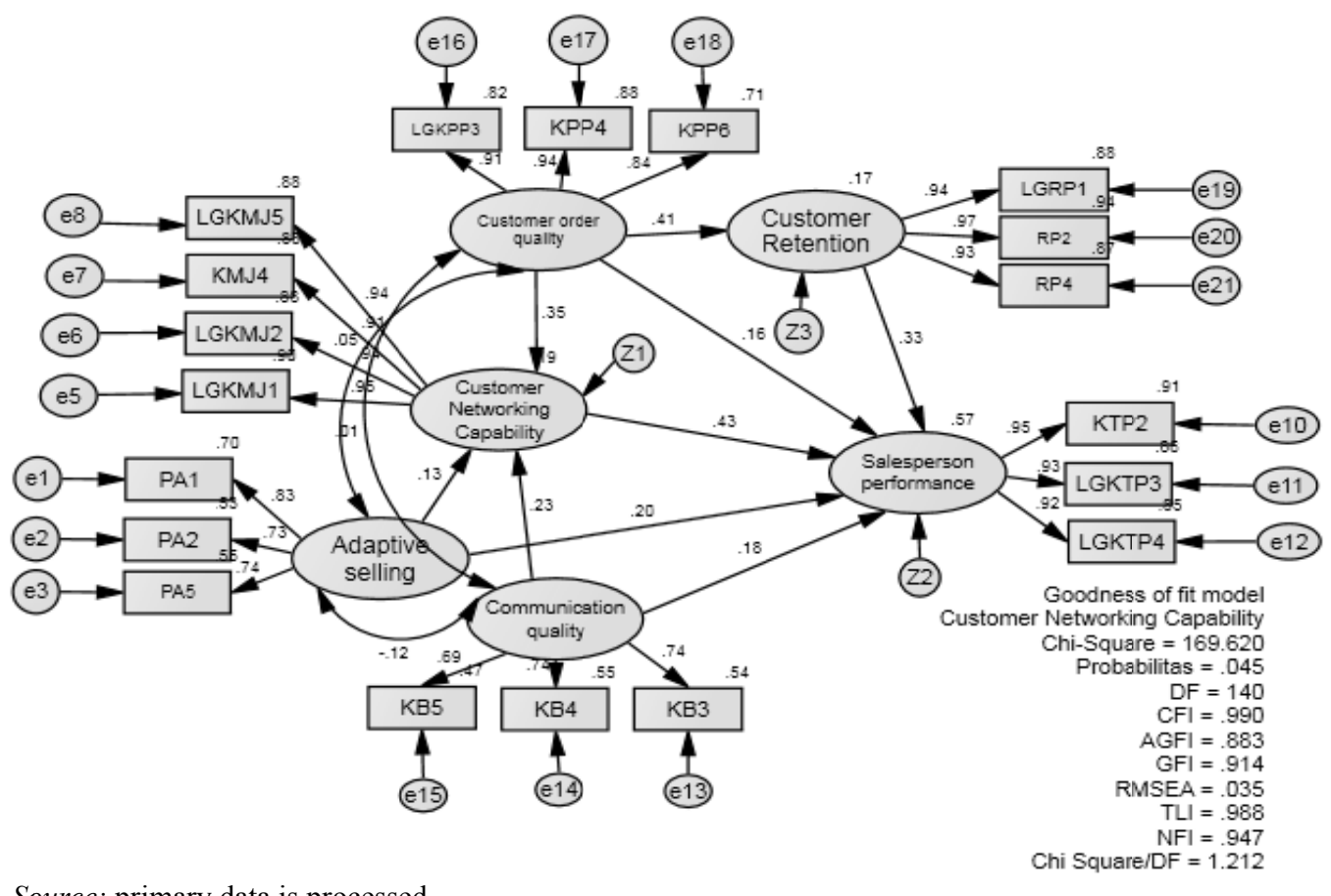

Source: primary data is processed

Figure 2. Revised model: customer networking capability on salesperson's performance 
networking capability $(\mathrm{H} 1: \beta=.13, p<.09)$. There is a significant correlation between adaptive selling and a salesperson's performance (H2: $\beta=.20, p<.00$ ), and a significant positive correlation between customers' order quality and customer networking capability (H3: $\beta=.35, p<$ $.001)$. There are also significant positive correlations between communication's quality and the customer networking capability (H4: $\beta=$ $.23, p=<0.00)$; customers' order quality and customer retention (H6: $\beta=.201, p=<.001$ ); customer retention and the salesperson's performance $(\mathrm{H} 7: \beta=.33, p=<.00)$; customers' order quality (H8: $\beta=.17, p=<.001)$ and the salesperson's performance (H9: $\beta=.43, p=<$ $.00)$.

Customer networking capability plays an important role as an intervening variable in building the salesperson's performance. Thus, a salesperson must not rely on adaptive selling only, but also include a broad customer networking capability to influence his/her performance. The researcher identified that a broad customer network and the quality of the customers' orders contributes much more (H3: $\beta$ $=.33, p=<.013)$ than the other variables, the communication's quality ( $\mathrm{H} 4: \beta=.23, p=<$
$.006)$ or adaptive selling ( $\mathrm{H} 1: \beta=.13, p=<.09)$. From the nine hypotheses that were generated, eight are accepted, and one is rejected. The communication's quality (H5: $\beta=.41, p=<$ .000 ), customer networking capability (H6: $\beta=$ $.18, p=<.007)$ and customers' order quality (H7: $\beta=.33, p=<.000$ ), all have a positive impact on a salesperson's performance. The customers' order quality (H8: $\beta=.33, p=<$ $.000)$ and customer networking capability (H9: $\beta$ $=.43, p=<.00$ ), both have a positive impact on a salesperson's performance. Table 3 presents the results of testing the hypotheses.

\section{Testing a mediating role: customer networking capability}

The customer networking capability variable was tested to see if it acted as a mediating variable. The aim of testing for a mediating role is to test the importance of the role of the variable in overcoming the gap between adaptive selling and the salesperson's performance (Baron \& Kenny, 1986). This test determines the effect of mediation on structural equation modeling.

Table 3. Results of hypotheses testing

\begin{tabular}{llllll}
\hline & \multicolumn{1}{c}{ Path } & & $\boldsymbol{\beta}$ & Sig & Comment \\
\hline H1 Adaptive selling & $\rightarrow$ & Customer networking capability & .13 & .099 & Rejected \\
H2 Adaptive selling & $\rightarrow$ & Salesperson's performance & $.20^{* *}$ & .001 & accepted \\
H3 Customers' order quality & $\rightarrow$ & Salesperson's performance & $.35^{* * *}$ & .013 & accepted \\
H4 Communication's quality & $\rightarrow$ & Customer networking capability & $.23^{* *}$ & .006 & accepted \\
H5 Customers' order quality & $\rightarrow$ & Customer retention & $.41^{* * *}$ & .000 & accepted \\
H6 Communication's quality & $\rightarrow$ & Salesperson's performance & $.18^{*}$ & .007 & accepted \\
H7 Customer retention & $\rightarrow$ & Salesperson's performance & $.33^{* *}$ & .000 & accepted \\
H8 Customers' order quality & $\rightarrow$ & Salesperson's performance & $.16^{*}$ & .013 & accepted \\
H9 Customer networking capability & $\rightarrow$ & Salesperson's performance & $.43^{* * *}$ & .000 & accepted \\
\hline
\end{tabular}

$N=259 ; * p<.05, * * p<.01, p<.001$. 
Table 4. Testing the role of the importance of the customer networking capability variable.

\begin{tabular}{|c|c|c|c|c|c|c|c|c|}
\hline \multirow{2}{*}{ No } & \multirow{2}{*}{$\begin{array}{l}\text { Independent } \\
\text { Variable }\end{array}$} & \multirow{2}{*}{ Intervening Variable } & \multirow{2}{*}{$\begin{array}{l}\text { Dependent } \\
\text { Variable }\end{array}$} & \multicolumn{2}{|c|}{ Ind $\rightarrow$ dep } & \multicolumn{2}{|c|}{ Ind $\rightarrow$ Int $\rightarrow$ Dep } & \\
\hline & & & & Koef $\beta$ & Sign & Sobel test & Sign & \\
\hline 1 & $\begin{array}{l}\text { Adaptive } \\
\text { Selling }\end{array}$ & $\begin{array}{l}\text { Customer Networking } \\
\text { capability }\end{array}$ & $\begin{array}{l}\text { Salesperson's } \\
\text { performance }\end{array}$ & .20 & .001 & 3.376 & .009 & $\begin{array}{l}\text { Partial } \\
\text { mediation }\end{array}$ \\
\hline 2 & $\begin{array}{l}\text { Communicatio } \\
\text { n's quality }\end{array}$ & $\begin{array}{l}\text { Customer Networking } \\
\text { capability }\end{array}$ & $\begin{array}{l}\text { Salesperson's } \\
\text { performance }\end{array}$ & .18 & .007 & 3.600 & .000 & $\begin{array}{l}\text { Partial } \\
\text { mediation }\end{array}$ \\
\hline 3 & $\begin{array}{l}\text { Customers' } \\
\text { order quality }\end{array}$ & $\begin{array}{l}\text { Customer Networking } \\
\text { capability }\end{array}$ & $\begin{array}{l}\text { Salesperson's } \\
\text { performance }\end{array}$ & .16 & .013 & 3.142 & .000 & $\begin{array}{l}\text { Partial } \\
\text { mediation }\end{array}$ \\
\hline
\end{tabular}

Based on Table 4, it can reported as follows: first, the results of the analysis of the adaptive selling, the salesperson's performance and customer networking capability show significant results with the Sobel test statistical value of 3.376 and the probability of .009 . Furthermore, the results of the analysis of the adptive selling and the salesperson's performance excluding customer networking capability also show significant results with the beta coefficient of 20 and the probability value of .001 . Thus, it can be concluded that the customer networking capability variable is partially mediated.

Second, the results of the analysis of the communication quality, salesperson's performance and customer networking capability show significant results with the Sobel test value of 3.600 and the probability of .000 . Furthermore, the results of the analysis of the communicationquality variable and the salesperson's performance excluding customer networking capability variable show significant results with the beta coefficient of .18 and the probability value of .007. Thus, it can be concluded that the customer networking capability variable is partially mediated.

Third, the results of the analysis of the customers' order quality, the salesperson's performance and customer networking capability show significant results with the Sobel test value of 3.142 and the probability value of .000 . Furthermore, the results of the analysis of the customers' order quality and the salesperson's performance excluding the customer networking capability show significant result with the beta coefficient of .16 and the probability value of .013 . Thus, it can be concluded that the customer networking capability variable is partially mediated.

\section{DISCUSSIONS}

Adaptive selling, customers' order quality, and communication's quality have a significant and positive impact on customer networking capability and a direct or indirect effect on the salesperson's performance. The customer networking capability acts as an intervening variable between adaptive selling and a salesperson's performance. The extended customer networking is a new strategy that can be used by a salesperson doing his/her job. If it is done well, the salesperson's performance will be better.

Developing a customer network is the most important aspect of marketing but it has not yet received much attention from especially salespeople (Kumar et al., 2014; Mullins, Ahearne, Lam, Hall, \& Boichuk, 2014). It is expected that a salesperson optimalizes their customer networking capability to raise his/her performance; this has the potential to help the salesperson do their job (Gabler et al., 2014; Korschun et al., 2014). Customer networking can develop if the salesperson and customer can maintain their trust in each other and be ready and open minded to accept changes. Based on the research finding, we offer a practical 
suggestion to salespeople to expand their customer networking

There has been limited research into the impact of customer networking capability on a salesperson. For this reason, we are interested in conducting research into the performance of salespeople. The understanding of customer networking on a salesperson is essential. A broad customer network tends to raise the salesperson's performance (Mullins et al., 2014). The research findings show that adaptive selling, communication's quality, and customers' order quality have a significant positive impact on the networking capability. Thus, the better the salesperson understands the emotions of the customer, the better their performance will be.

The role of customer networking capability is one of the strategies that can be used to improve a salesperson's performance. It is in line with the research conducted by Milovanovic et al. (2016), which reported that a company that can develop a networking customer professionally will automatically broaden the network. The extended network enables companies to sucessfully develop their sales force's performance. In addition, the research conducted by Kim et al. (2015) shows that with a broad networking customer, the salesperson can do many things: they will find it easier to know and meet the customer's needs, and be able to overcome the customer's complaints right away.

A broad network creates additional expenses for the company, because they need to maintain it (Huang \& Rice, 2012). The additional expense can be excessive or extravagant if the salespeople are not careful in choosing the quality of the consumer's network. A well-networked customer is the one that can provide the most benefit to the salesperson and the consumer. In other words, the quality of the customer network must be appropriate for the company, so it can make a profit and continue to operate for a long time.

In addition, the culture, ethics and communication skills of the customer determine the success of the salesperson in developing his/her customer networks (Agnihotria and Krush, 2015). The salesperson must have the capability to comprehend their culture, ethics, and communication skills. Every place has its own norms, ethics and customs that need to be understood by the salesperson. The success in developing a synergizing customer network is determined by knowing and understanding the local customs and culture.

Adaptive selling, customerrs' order quality, communication, communication's quality, and customer retention have a significant positive effect on the salesperson's performance. The variable that has the most influence on the increase in a salesperson's performance is the commnication's quality. This can be seen from the fact that the estimated coefficient of all these variables has the largest coefficient, namely 0.51. This is in accordance with the research carried out by Agnihotria and Krushb (2015), the communication's quality of a salesperson is crucial to increasing that salesperson's performance.

\section{CONCLUSION AND SUGGESTION}

\section{Conclusions}

This study analyzes the effect of adaptive selling, the customers' order quality, the communication's quality, and customer retention on the performance of salespeople, with customer networking capability as the intervening variable. Based on the results of the hypotheses tests, this study concludes that customer networking capability can link adaptive selling and salespeoples' performance. Additionally, the quality of the customers' order, customer 
retention and the quality of the communications have a significant positive impact on the salesperson's performance. Adaptive selling has a significant positive effect on a salesperson's performance, but it does not have an effect on customer networking capability.

\section{Suggestions}

For salespeople, marketing managers, and the owners of companies, the researchers offer some managerial implications that can be implemented in policies that could benefit their corporations. The results of the research indicate that customer networking capability, as the intervening variable, can fill the gap between adaptive selling and a salesperson's performance. The indicators for customer networking capability in this research are developing the benefits of networking, improving an emotional relationship, developing continuous collaborations with customers, and sharing experiences that can improve the salesperson's performance.

In implementing the policy, the sales manager should coordinate with his salesperson who know the real conditions in the field. This must be done to increase effectiveness and efficiency of the salesperson, and to save unnecessary expenses by the company. The company should pay special attention to the salesperson who has the best performance, who is probably the one who can broaden a new networking customer. The appreciation can be in form of an interesting incentive or a foreign holiday. Broad customer networking and good communication skills can raise a salesperson's performance.

This research has several limitations that offer opportunities for future research. Firstly, the research's results cannot be generalized because of the sample's limitation. The samples in this study were only salespeople from the soft drinks' industry. The salespeople should be from various industries, both service industries and manufacturing industries. Besides that, the sales profession requires special skills, in accordance with the types of products and their complexity. A special skill can be a physical presence, a warm personality, a good education, and wide knowledge about the product and its function. Secondly, the researchers believe that there are other variables that can improve a salesperson's performance, besides their customer networking capability, communication skills, and customer retention; attributes such as working hard, the quality of the customers' orders, using technology to help the sales process, and so on.

Thirdly, there is no dynamic interaction between researchers and respondents because the research's design is a cross-section. To establish a dynamic interaction, it needs longitudinal data. Fourthly, measuring salespeople's performance requires another indicator besides those of the market share's growth, selling growth, exceeding the company's sales target, or the number of new customers; it needs another indicator for example, the direct involvement of managers. Finally, due to limited funding and time, the researchers had to limit the scope of the study. However, the results of the study are expected to answer the research problem.

The success achieved by a salesperson is determined by many factors. Thus it is necessary to involve the role of the marketing manager. The marketing manager can direct the salespeople to implement established marketing strategies. If sales increase so does the sales' performance, and all the related parties feel this, as the performance of the company will also increase.

Finally, the empirical testing model in this research cannot be classifed as very good, but only as fits the model. This is because the values of the testing criteria of reference, and the test criteria's suitability and stastistical test are very 
close to the standardized criterion values, as a result of the ability to explain the relationship between the variables being low.

\section{REFERENCES}

Abdul-Hafez, B., \& Al-Nady, A. (2016). The role of time, communication, and cost management on project management success: an empirical study on sample of construction projects customers in Makkah City, Kingdom of Saudi Arabia. Int. J. Services and Operations Management, Vol. 23 (No. 1 ), pp. 76 - 113.

Abed, G. M., \& Haghighi, M. (2009). The effect of selling strategies on sales performance. Business Strategy Series Vol. 10, pp. 266 228.

Agnihotria, R., \& Krushb, M. T. (2015). Salesperson empathy, ethical behaviors, and sales performance: the moderating role of trust in one's manager. Journal of Personal Selling \& Sales Management, 35(2), 164 174.

Amyx, D., \& Jarrell, L. (2016). The influence of salesperson depression, low performance, and emotional exhaustion on negative organizational deviance. Journal of Managerial Issues, 27(3-4), 127 - 144.

Ang, L., \& Buttle, F. (2006). Managing for successful customer acquisition: an exploration. Journal of Marketing Management, 22, 295 - 317.

Baron, R. M., \& Kenny, D. A. (1986). The moderator-mediator variable distinction in social psychological research: strategic, and statistical considerations. Journal of Personality and Psychology, Vol. 51(no. 6), pp. 1173 - 1182.

Basir., M. S., \& Ahmad, S. Z. (2010). The relationship between sales skills and salesperson performance: en empirical study in the Malaysia Telecommunications Company.

Bolander, W., Satornino, C. B., Hughes, D. E., \& Ferris, G. R. (2015). Social Networks Within Sales Organizations: Their Develop- ment and Importance for Salesperson Performance. Journal of Marketing, Vol. 79 pp. 1 - 16

Cartera, R. E., Hendersonb, C. M., Arronizc , I., \& Palmatierd, R. W. (2014). Effect of salespeople's acquisition-retention trade-off on performance. Journal of Personal Selling \& Sales Management, 34(2), 91 - 111.

Chena, C.-C., \& Jaramillob, F. (2014). The double-edged effects of emotional intelligence on the adaptive sellingsalesperson-owned loyalty relationship. Journal of Personal Selling \& Sales Management, No. 34(No. 1), pp. 33 - 50.

Chow, W. (2015). Investigating customers' satisfaction with brand pages in social networking sites. The Journal of Computer Information Systems; , Vol. 55 ( No. 2 ), pp. $48-62$.

David A, L., Mulki, J. P., \& Weinberg, F. J. (2014). How Do Salespeople Make Decisions? The Role of Emotions and Deliberation on Adaptive Selling, and the Moderating Role of Intuition. Psychology and Marketing, Vol. 31(No. 6), pp. 387 403.

Drollinger, T., \& Comer, L. B. (2013). Salesperson's listening ability as an antecedent to relationship selling.

Fang Yulin, Israr Qureshi, Heshan Sun, Patrick McCole, Elaine Ramsey, \& Lim, K. H. (2014). Trust, satisfaction, and online repurchase intention: the moderating role of perceived effectiveness of e-commerce institutional mechanisms. MIS Quarterly 38(2), 407 - 427.

Ferdinand, A. T. (2014). Structural Equation Modeling in Management Research BP Undip - Undip Press.

Gablera, C. B., Rapp, A., \& Richeyb, R. G. (2014). The effect of environmental orientation on salesperson effort and participation: the moderating role of organizational identification. Journal of Personal Selling \& Sales Management, 34(3), 173 - 187. 
Gupta, A. (2016). Redefining service quality scale with customer experience quality scale: a critical review. Int. J. of Services and Operations Management, Vol. 25 ( No. 1 ), pp. 48 - 64

Hair, J., F., J., Black, W. C., Babin, B. J., \& Anderson, R. E. (2010). Multivariate Data Analysis Pearson Prentice Hall, seventh Edition.

Hajli, N., \& Lin, X. (2016). Exploring the security of information sharing on social networking sites: the role of perceived control of information. $J$ Bus Ethics(133), $111-123$.

Huang, H., \& Rice, J. (2012). Firm networking and bribery in china: assessing some potential negative consequences of firm openness. J Bus Ethics (2012) 107:533-545, 533-545.

Hughes, D. E., Bon, J. L., \& Rapp, A. (2013). Gaining and leveraging customer-based competitive intelligence: the pivotal role of social capital and salesperson adaptive selling skills. J. of the Acad. Mark. Sci., 41, $91-110$.

Imam, G. (2011). Model Persamaan Bertingkat Konsep dan Aplikasi dengan Program AMOS 210. Badan Penerbit Universitas Diponegoro, ISBN: 979.704.233.2.

Jayakody, J. A. S. K., \& Sanjeewani, W. M. A. (2006). The impact of salesperson transformation leaderhip behavior on customer relationship marketing behavior. International Journal of Bank Marketing

Jonathan, V. L., \& Johnmark, D. R. (2012). The impact of employee empowerment on customer satisfaction in the nigerian service organizations (a study of some selected hotels in Jos, Plateau State). International Journal of Curret Research and Review, 04(19), 37 - 52.

Kantor Pusat Statistik Indonesia. (2016). Statistik Industri Manufaktur. (6103014), 58-61.

Kenny, B., \& Fahy, J. (2011). Smes' networking capability and international performance.
Interfirm Networks: Theory, Strategy, and Behavior, 17, 199-327.

Klerk, S. d. (2014). The importance of networking as a management skill. S.Afr.J.Bus.Manage., 41 (1), 37

Kumar, V., Sunder, S., \& Leone, R. P. (2014). Measuring and managing a salesperson's future value to the firm. Journal of Marketing Research, L I, 591 - 608.

Le, N. T. B., \& Nguyen, T. V. (2009). The impact of networking on bank financing: the case of small and medium-sized enterprises in Vietnam. Entrepreneurship Theory and Practice.

Liu, T.-C., \& Wu, L.-W. (2007). Customer retention and cross-buying in the banking industry: An integration of service attributes, satisfaction and trust. Journal of Financial Services Marketing, 12(2), 132 145.

Luo, X., Hsu, M. K., \& Liu, S. S. (2008). The moderating role of institutional networking in the customer orientation-trust/ commitment-performance causal chain in China. Journal of the Academy Marketing Science 36, 202-214.

Mariana, R. (2013). The Performance of Retailing Mix and Customer Relationship Management for Incressing Customer valuue and Corporate Image of Pertamina Gasolin Station for Public Use ( a Survey on Pertamina of Gasolin Station for Public Use Customer in Job Region I). Journal of Global Management, 6(1), 77 - 88.

Maroofi, F., Sadegh, F., Sadegh, G., \& Fathi, D. (2011). Adaptive Selling Behavior In Iran Automobile Sales Representatives. International Journal of Academic Research, Vol. 3.

Miao, C. F., \& Evans, K. R. (2012). The Interactive effects control system on salesperson performance: a job demands-resources perspective. Academy of Marketing Science.

Milovanovic, M. B., Primorac, D., \& Geran, K. (2016). Two dimensional analysis the inlfuence of strategi networking on 
entrepreneurial and business performance among SME,s. Duodimejiska Analiza Utjecaja Umrezavanja, 23(1), 247 - 255.

Mullins, R. R., Ahearne, M., Lam, S. K., Hall, Z. R., \& Boichuk, J. P. (2014). Know Your customer: how salesperson perceptions of customer relationship quality form and influence account profitability. Journal of Marketing, Vol. 78 pp. 35 - 38

Orpen, C. (1997). The interactive effects of communication quality and job involvement ... The Journal of Psychology, 131(5), 519.

Ozdemir, V. E., \& Hewett, K. (2010). The Effect of collectivism on the importance of relationship quality and service quality for behavioral intentions: a cross-national and cross-contextual analysis. Journal of International Marketing, Vol. 18 (No. 1 ), pp. 41-62

Park, J.-G., \& Lee, S. L. a. J. (2014). Communication effectiveness on IT service relationship quality. Industrial Management \& Data Systems, 114(2), 321 - 336.

Paschal, A. U., \& Eid, R. (2011). Integrating internal customer orientation, internal service quality, and customer orientation in the banking sector: an empirical study. The Service Industries Journal Vol. 31, No. 14, November 2011, 2487-2505.

Pettijohn., C. E., Pettijohn, L. S., Paylor, A., \& Keilor, B. D. (2007). Adaptive Selling and Sales Performance an Empirical Examination. The Journal of Applied Business Research, 16 No. 1.

Phillips, M., McFadden, D. T., \& Sullins, M. (2010). How Effective is social networking for direct marketers? Journal of Food Distribution Research, 41(1), 96-100.

Pitt, L. F., Bertohon, P. R., \& Robson, M. J. (2000). Communication apprehension and peerceptions of salesperson performance: a multinational perspective. Journal of Managerial Psychology, 15(1), 68-86.

Portera, S. S., Wienerb, J. L., \& Frankwick, G. L. (2003). The moderating effect of selling situation on the adaptive selling strategy- selling effectiveness relationship. Journal of Business Research Vol. 56 pp. 275-281

Rapp, A., Ahearne, M., Mathieu, J., \& Schillewaert, N. (2006). The impact of knowledge and empowerment on working smart and working hard: The moderating role of experience. International Journal of Research in Marketing, 23, 279-293.

Schillewaert, N., \& Ahearne, M. (2001). The effects of Information Technology on Salesperson Performance. I S B M Report

Schwepker, J. C. H., \& Schultzb, R. J. (2015). Influence of the ethical servant leader and ethical climate on customer value enhancing sales performance. Journal of Personal Selling \& Sales Management, Vol. 35(No. 2), pp. $93-107$.

Setia, P., Venkatesh, V., \& Joglekar, S. (2013). Leveraging digital technologies: how information quality leads to localized capabilities and customerservice performance. MIS Quarterly 37(2), 565 - 590.

Shoemaker, M. E., \& Pelham, A. M. (2013). Does salesperson perception of the firmlevel of market orientation influence sales behavior and performance attributions? Journal of Managerial Issues, 25(4), 381400. Retrieved from

http://search.ebscohost.com/login.aspx?dire $\mathrm{ct}=$ true \&AuthType $=\mathrm{ip}$, shib\&db=pbh\&AN= $96087759 \&$ site $=$ ehost live $\&$ scope $=$ site \&custid $=$ ns 003811 .

Shpëtim Çerri. (2012). Exploring factor affecting trust and relationship quality in a supply chain context. Journal of Business Studies Quarterly, 4(1), 74-90.

Singh Saini, M., \& Moon, G. (2013). Social networking sites: a premise on enhancement. Journal of Internet Banking and Commerce, 18(13).

Stahl, F., Heitmann, M., Lehmann, o. R., \& Neslin, S. A. (2012). The impact of brand equity on customer acquisition, retention, and profit margin. Journal of Marketing, 76, $44-63$. 
Tawinunt, K., Phimonsathien, T., \& Fongsuwan, W. (2015). Service quality and customer relationship management affecting customer retention of longstay travelers in the Thai tourism industry: a sem approach. International Journal of Arts \& Sciences, Vol. 8 (No. 2), pp. 459 - 477.
Yao, Q., Chen, R., \& Cai, G. (2013). How internal marketing can cultivate psychological empowerment and enhance employee performance. Social Behavior and Personality, 41(4), 529 - 538. 